\title{
Optical single cylinder engines in engine research and development
}

\begin{abstract}
We report on essential design elements of optically accessed research engines and describe selected examples of their applications in engine development. Whereas research topics most often address specific generic topics and are focused on comprehensive analysis of selected engine phenomena, the priority in using optical engines for engine development tasks is in providing data relevant for the operation of a normal multicylinder engine. In this latter case, optical engines are only used if their results have such high value that they justify the efforts required to achieve the outcome. Both, research and development applications, benefit from each other as they promote progress in optical engine technology as well as in application of new analysis techniques.
\end{abstract}

Key words: combustion engine, optical research, combustion process, air-fuel mixture formation

\section{Jednocylindrowy silnik optyczny w badaniach i rozwoju silników spalinowych}

\begin{abstract}
W artykule omówiono podstawowe elementy konstrukcyjne silnika badawczego z dostępem optycznym i opisano wybrane przyklady ich zastosowania w pracach rozwojowych dotyczacych silników spalinowych. Wprawdzie tematy badawcze najczęściej odnoszą się do specyficznych szczegółowych zagadnień badawczych i sa skupione na wszechstronnej analizie wybranych zjawisk silnikowych, jednak pierwszeństwo w wykorzystaniu silników optycznych do silnikowych zadań rozwojowych polega na zapewnieniu właściwych warunków pracy normalnego silnika wielocylindrowego. $W$ odniesieniu do silników wielocylindrowych silniki optyczne sq używane tylko wówczas, gdy uzyskane z nich wyniki maja tak istotna wartość, że usprawiedliwiaja poniesione $w$ tym celu naktady. Zastosowania badawcze i rozwojowe uzupetniaja się, wspomagając rozwój postępu w technologii silników optycznych oraz w wykorzystaniu nowych technik analizy procesów i zjawisk.
\end{abstract}

Słowa kluczowe: silnik spalinowy, badania optyczne, proces spalania, tworzenie mieszaniny paliwowo-powietrznej

\section{Introduction}

The use of "thermodynamic" single cylinder engines (TSCE) in engine R\&D becomes ever more important as such engines provide a versatile environment for the test of basic modules and processes related to engine operation. Diagnostic instrumentation of a TSCE is less complex as compared to a multicylinder engine (MCE) and the simpler mechanical structure provides more flexibility in applying refined diagnostic access. For specific optical flow and combustion analysis, it has become common practice to use an extended crankcase design with a "Bowditch" piston configuration. The aim of this paper is in addressing questions as to the use of TSCEs versus MCEs, and in particular to focus on topics related to "optical" single cylinder engines (OSCE).

It is common practice to use TSCEs or OSCEs to work on fundamental engine research topics. Their application to support engine development projects, however, has taken a long time, as considerable efforts and cost must be offset by the benefits achieved with single cylinder results. With growing complexity of engine and combustion system development, it is now more economical to perform well defined development and test procedures in a TSCE rather than in a normal MCE configuration. A typical example of such development applications is the base calibration of GDI fuel injection systems.

SCE systems and their peripheral equipment have in some detail been described recently [1]. This paper gives an overview of OSCE configurations and their use in GDI engine development.

\section{Wprowadzenie}

Zastosowanie jednocylindrowego silnika "termodynamicznego" (TSCE) w badaniach silnikowych i pracach rozwojowych staje się coraz ważniejsze i stwarza szerokie możliwości prowadzenia testów podstawowych układów silnikowych i procesów związanych z pracą silnika. Oprzyrządowanie diagnostyczne silnika TSCE jest mniej złożone w porównaniu do silnika wielocylindrowego (MCE), a jego prostsza struktura mechaniczna zapewnia większą swobodę w zastosowaniu wyspecjalizowanego dostępu diagnostycznego. Dla specjalistycznej optycznej analizy przepływu i spalania powszechną praktyką stało się stosowanie zmodyfikowanej konstrukcji kadłuba silnika i owalnie wyciętego tłoka. Celem tej publikacji jest sformułowanie pytań dotyczących zastosowania jednocylindrowego silnika termodynamicznego w stosunku do silnika wielocylindrowego, a w szczególności zwrócenie uwagi na zagadnienia odnoszące się do optycznych silników jednocylindrowych (OSCE).

Obecnie powszechną praktyką jest stosowanie jednocylindrowego silnika „termodynamicznego" (TSCE) lub jednocylindrowego silnika optycznego do badań silnikowych typu podstawowego. Ich wykorzystanie do wspomagania silnikowych projektów rozwojowych wymaga jednak długiego czasu, a przewidywany wysiłek i koszty muszą być kompensowane zyskami osiągniętymi dzięki wynikom uzyskanym z silnika jednocylindrowego. Wraz ze wzrastającą złożonością rozwoju silnika i systemu spalania nie jest obecnie ekonomicznie uzasadnione prowadzenie dobrze 


\section{MCE - TSCE - OSCE}

Research applications of TSCEs are clearly defined by respective research topics, the engine's main purpose is to provide well defined and relevant engine conditions and to enable diagnostic access. The focus in using a TSCE for engine development is in duplicating engine conditions which are specific to the actual MCE, such as airflow or fuel injection in case of mixture formation development. The benefit in using a TSCE might be faster availability of hardware variants or the access for imaging techniques in an OSCE. Table 1 gives a comparison of engine features and shows benefits of either variant with respect to engine operation or diagnostic access. The benefit of TSCEs or OSCEs is seen in applicability of diagnostic instrumentation. This is especially relevant in the development of clean and efficient DI combustion systems. Development for transient engine operation, however, and refinement of thermal behavior is a specific task reserved to MCE testing. MCE is benchmark on performance related topics, TSCE has benefit of one cylinder only in stationary combustion and emissions related development, OSCE provides best sensor and optical access, but has limits due to heat transfer features. zdefiniowanych procedur rozwojowych i badawczych w silnikach 1-cylindrowych ,termodynamicznych”, zamiast w normalnych silnikach wielocylindrowych. Typowym przykładem takich zastosowań badawczych jest podstawowa kalibracja systemów bezpośredniego wtrysku paliwa typu GDI.

Silniki jednocylindrowe i ich wyposażenie pomiarowe zostały ostatnio opisane w odniesieniu do wybranych szczegółów konstrukcyjnych w pracy [1]. To opracowanie zawiera przegląd jednocylindrowych silników „optycznych” (OSCE) i ich wykorzystania w rozwoju silnika typu GDI.

\section{Silnik wielocylindrowy - „termodynamiczny” silnik jednocylindrowy - jednocylindrowy silnik optyczny}

Badawcze zastosowania jednocylindrowego silnika "termodynamicznego" są wyraźnie zdefiniowane przez odpowiednie cele badawcze; głównym zadaniem takiego silnika jest zapewnienie dobrze zdefiniowanych i odpowiednich parametrów silnikowych i umożliwienie dostępu diagnostycznego. Istotą zastosowania silnika ,termodynamicznego” do prac rozwojowych jest odtworzenie warunków silnikowych właściwych dla odpowiedniego silnika wielocylindrowego, takich jak przepływ powietrza lub wtrysk paliwa w odniesie-

Table 1. Multi- and single cylinder engine comparison

Tabela 1. Porównanie silników wielo- (MCE) i jednocylindrowego

\begin{tabular}{|c|c|c|c|}
\hline Engine feature/cecha silnika & MCE & TSCE & OSCE \\
\hline Speed range/zakres prędkości obrotowej & +++ & +++ & + \\
\hline Load range/zakres obciążenia & +++ & +++ & + \\
\hline Thermal environment/środowisko cieplne & +++ & ++ & + \\
\hline Gas exchange/wymiana ładunku & +++ & ++ & + \\
\hline $\begin{array}{l}\text { Dynamic response/transient operation/dynamika reak- } \\
\text { cji/praca nieustalona }\end{array}$ & +++ & + & No \\
\hline Stationary operation/praca ustalona & +++ & +++ & + \\
\hline Sensor access/dostęp dla czujników pom. & + & ++ & +++ \\
\hline Optical access/dostęp optyczny & + & + & +++ \\
\hline \multicolumn{4}{|l|}{ Emissions/emisja } \\
\hline Measurement/pomiary & +++ & +++ & + \\
\hline Understand root cause/zrozumiała przyczynowość & + & ++ & +++ \\
\hline Mixture formation/tworzenie mieszanki & + & + & +++ \\
\hline $\begin{array}{l}\text { Modularity for components test/modułowość dla badań } \\
\text { elementów konstrukcyjnych }\end{array}$ & + & +++ & +++ \\
\hline
\end{tabular}

\section{Optical access: endoscopes versus large windows in OSCE}

Why should we use large windows in an OSCE when small window bores or fiber optic sensors may also provide access into the combustion chamber of an MCE or TSCE? The main benefit of large windows in an OSCE is the large optical throughput (or aperture) when combined with an optical imaging or radiation measurement system and the large field of view inside the combustion chamber. Combination of glass liner with a window in the piston or head, further extends the applicability of diagnostic systems. niu do rozwoju powstawania mieszanki. Zaletą stosowania jednocylindrowego silnika ,termodynamicznego" może być szybsza dostępność wariantów konstrukcyjnych lub dostęp optyczny dla technik filmowania w jednocylindrowym silniku optycznym. W tabeli 1 przedstawiono porównanie właściwości silników i ukazano korzyści każdej wersji silnikowej w odniesieniu do pracy silnika i dostępu diagnostycznego. Zalety silnika „termodynamicznego” lub „optycznego” są widoczne w stosowalności oprzyrządowania diagnostycznego. To jest szczególnie istotne w rozwoju niskoemisyjnych i wydajnych systemów spalania. Jednak badania rozwojowe 
Endoscope access is applied to MSCE or TSCE analysis with the benefit of unrestricted engine operation, but at the disadvantage of small optical throughput and limited flexibility in the application of complex optical analysis systems.

The following chapters describe basic design elements of an OSCE, their modes of operation and give examples of in-cylinder analysis results.

\section{The extended crankcase design of an OSCE}

The basic design elements of an OSCE are given in the schematic of Fig. 1 together with the elongated piston modules and a photograph of an optical GDI engine. This extended crankcase design serves two purposes:

1. The separation of the lube oil in the base engine from the "dry" area of the combustion chamber.

2. The ability to use a piston window together with a $45^{\circ}$ mirror for a bottom view into the combustion chamber.

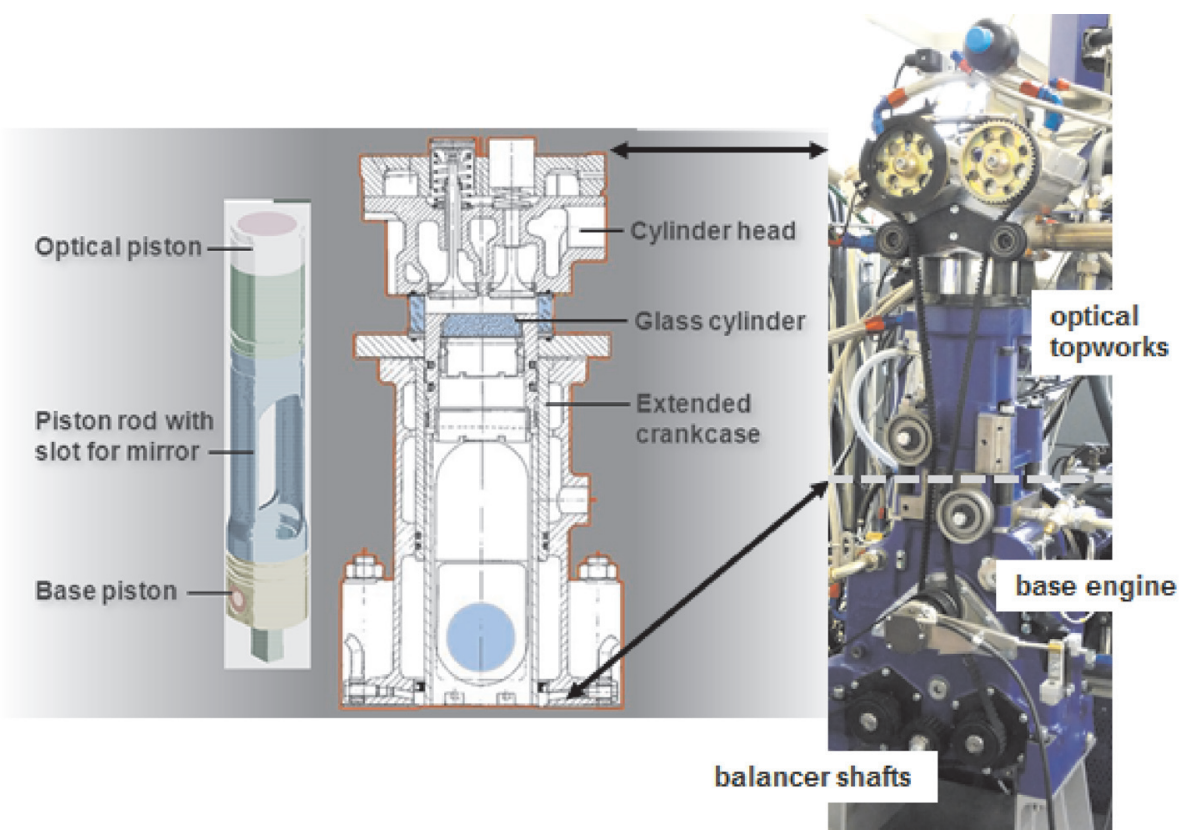

Fig. 1. Specific modules and complete assembly of an OSCE

Rys. 1. Poszczególne elementy i kompletny silnik typu OSCE

w odniesieniu do nieustalonych warunków pracy silnika i doskonalenie warunków cieplnych są specjalnym zadaniem zarezerwowanym dla badań silników wielocylindrowych (MCE). MCE jest podstawą zagadnień odnoszących się do osiągów, TSCE wykazuje zaletę jednego cylindra tylko w ustalonych warunkach spalania i w pracach rozwojowych dotyczących zmniejszenia emisji. OSCE zapewnia najlepszy dostęp pomiarowy i optyczny, ale wykazuje ograniczenia ze względu na właściwości przewodzenia ciepła.

\section{Dostęp optyczny: endoskopy w porównaniu do dużych wzierników w silnikach OSCE}

Dlaczego powinniśmy używać dużych wzierników w silnikach optycznych (OSCE), jeżeli małe otwory wziernikowe lub czujniki światłowodowe mogą także zapewnić dostęp optyczny do komory spalania silnika wielocylindrowego (MCE) lub silnika „termodynamicznego” (TSCE)? Główną korzyścią stosowania dużych wzierników w silnikach optycznych (OSCE) jest duża optyczna przepuszczalność, gdy są stosowane $\mathrm{w}$ połączeniu $\mathrm{z}$ optycznym filmowaniem lub systemem pomiaru promieniowania i dużym polem obserwacji komory spalania. Połączenie szklanego cylindra z oknem w tłoku lub głowicy zwiększa możliwości stosowania systemu diagnostycznego.

Dostęp endoskopowy jest stosowany $\mathrm{w}$ analizie silników wielocylindrowych lub ,termodynamicznych" (TSCE), nie ograniczając warunków pracy silnika, ale jest związany z niedogodnością małej optycznej przepuszczalności i ograniczonej elastyczności w zastosowaniu złożonych systemów analizy optycznej. Kolejne rozdziały opisują podstawowe elementy

In order to provide high flexibility in assembling and operating such engines, many peripheral modules such as heat exchangers, lube oil and coolant pumps, or high pressure fuel supply systems are separated from the engine.

Operating limits of an OSCE arise from piston inertia forces acting upon conrod and related bearings and from thermal piston expansion in response to heat input from piston ring friction, compressed air and combustion. An optical piston has significantly higher mass than a normal piston. The oscillating mass forces introduced into the engine structure are balanced with first order counter rotating shafts; in specific applications second order shafts may further reduce engine vibrations.

The main limitation in operating an OSCE arises from thermal piston expansion. Piston cooling in an OSCE is achieved with heat transfer to the air on the bottom of the konstrukcyjne jednocylindrowego silnika optycznego (OSCE), rodzaje ich pracy i podają przykłady wyników analizy procesów wewnątrzcylindrowych.

\section{Konstrukcja wydłużonego bloku cylindrowego jednocylindrowego silnika optycznego}

Podstawowe elementy konstrukcyjne silnika optycznego (OSCE) przedstawiono na rys. 1 razem z przedłużonym tłokiem i zdjęciem silnika optycznego typu GDI. Taka konstrukcja wydłużonego bloku cylindrowego służy dwóm celom:

1. Oddzielenia oleju smarującego w silniku bazowym od „czystej” przestrzeni komory spalania.

2. Umożliwienia zastosowania okna w tłoku razem z lustrem $45^{\circ}$ dla obserwacji komory spalania od dołu. 
optical piston. This can be enhanced with an air jet cooling nozzle, but the resultant heat transfer is still inferior to the oil jet cooling of a normal piston. Consequently, engine operation must be adjusted to these thermal limitations. This imposes limits to maximum engine speed, and, specifically to the number of consecutively fired cycles. Even so, as is shown in Fig. 2, with precise control and automatic safeguard of engine operation, boosted high load operation for a GDI engine configuration is achievable.

A further consequence of these thermal features is the risk of self ignition events in a spark ignition (SI) OSCE. The risk of endgas self ignition (i.e. knock) is controlled with retarded spark timing. Pre-ignition events are detected with a real time pressure analyzer in order to cut fuel supply in consecutive cycles.

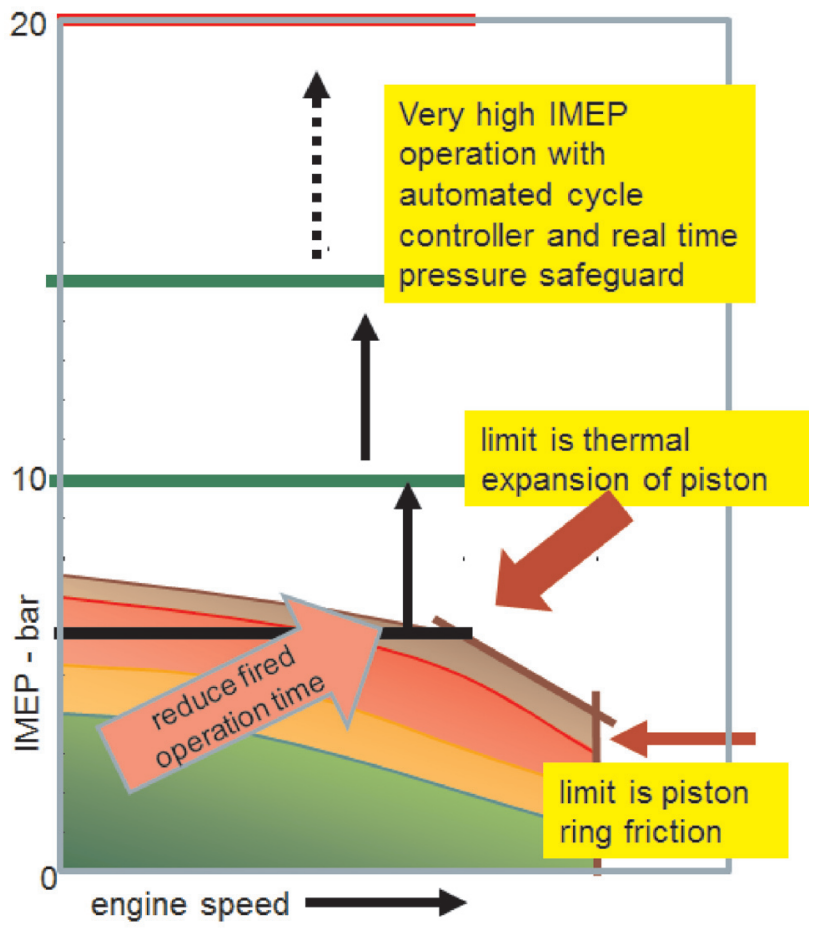

Fig. 2. Limits to the operation of a fired, stoichiometric SI engine Rys. 2. Ograniczenia warunków pracy silnika o ZI pracujacego na mieszance stechiometrycznej

\section{Optical piston design parameters}

The schematic of an optical piston in Fig. 1 shows base piston, piston rod and piston crown with a flat window insert. The requirements for such piston include:

- high mechanical stiffness of piston rod,

- piston guide rings to minimize/avoid lateral piston motion,

- oil drain on base piston,

- gasket ring on piston crown has contact to metal liner part only,

- piston to liner clearance must account for thermal piston expansion.

The components of such piston are shown in Fig. 3 with piston crown variants for GDI applications. In case that
W celu zapewnienia dużej swobody w kompletowaniu takich silników i ich pracy, wiele urządzeń pomocniczych, jak wymienniki ciepła, pompy oleju smarującego i cieczy chłodzącej, wysokociśnieniowe systemy zasilania paliwem, oddziela się od silnika.

Ograniczenia operacyjne silnika typu OSCE powstają w wyniku działania sił bezwładności poprzez korbowód i odpowiednie łożyska, i w wyniku cieplnej rozszerzalności tłoka wynikającej z dopływu ciepła od tarcia pierścieni tłokowych, sprężanego powietrza i spalania. Tłok silnika optycznego ma znacznie większą masę niż tłok konwencjonalny. Siły pochodzące od drgających mas wprowadzonych do silnika są wyrównoważone dzięki wałkom wyrównoważającym siły 1. rzędu; w specjalnych zastosowaniach wałki wyrównoważające siły 2 . rzędu mogą redukować drgania silnika.

Główne ograniczenia pracy silnika optycznego (OSCE) wynikają z cieplnej rozszerzalności tłoka. Chłodzenie tłoka w silniku OSCE uzyskuje się przez przekazanie ciepła do powietrza w dolnej części tłoka optycznego. Może ono być wzmocnione przez zastosowanie dyszy nadmuchu powietrza, ale wynikająca $\mathrm{z}$ niego wymiana ciepła jest nadal gorsza od chłodzenia konwencjonalnego tłoka przez natrysk oleju. W rezultacie praca silnika musi być dostosowana do tych obciążeń cieplnych. To nakłada ograniczenia na maksymalną prędkość obrotową silnika, a szczególnie na liczbę kolejnych cykli spalania. Ale nawet wówczas, tak jak pokazano na rys. 2, stosując precyzyjne sterowanie i automatyczne zabezpieczenie pracy silnika, możliwa jest do osiągnięcia praca doładowanego silnika typu GDI przy dużych obciążeniach.

Dalszą konsekwencją tych właściwości cieplnych jest niebezpieczeństwo wystąpienia samozapłonu w silniku typu OSCE o zapłonie iskrowym. Ryzyko samozapłonu reszty spalin (tzn. spalania stukowego) jest ograniczane przez opóźnienie zapłonu. Przedwczesny zapłon jest wykrywany przez analizator ciśnienia w cylindrze działający w czasie rzeczywistym i powoduje odcięcie dawki paliwa w następnych cyklach.

\section{Parametry konstrukcyjne tloków optycznych}

Schemat tłoka optycznego na rys. 1 pokazuje tłok zasadniczy, przedłużony płaszcz łłoka i koronę tłoka z płaskim wziernikiem optycznym. Wymagania dotyczące takiego tłoka obejmują:

- dużą sztywność mechaniczną płaszcza tłoka,

- tłokowe pierścienie prowadzące dla likwidacji przemieszczenia bocznego,

- odprowadzenia oleju w tłoku zasadniczym,

- pierścień uszczelniający w koronie tłoka styka się tylko z metalową częścią tulei,

- luz pomiędzy tłokiem i tuleją cylindrową musi uwzględniać cieplną rozszerzalność tłoka.

Elementy składowe takiego tłoka przedstawiono na rys. 3 z różnymi wariantami korony dla silnika typu GDI. Gdy pierścienie uszczelniające nie mogą się stykać ze szklaną częścią tulei cylindrowej, wówczas są umieszczane w dolnym końcu korony tłoka i ślizgają się tylko po metalowej 
gasket rings must not contact the glass liner, they are positioned on the lower end of the piston crown and glide on the metal liner part only. This implies a noticeable reduction of engine compression ratio.

\section{Compression ratio considerations}

Piston rings in an OSCE are most often on lower positions than in a normal piston. This low ring position together with a typical piston to liner clearance of $0.5 \mathrm{~mm}$ adds to the dead volume of the combustion chamber and reduces compression ratio between 1 and 3 units.

In an SI engine, such CR reduction is most often acceptable as the primary aim of an OSCE is the analysis of mixture formation during intake and compression stroke. In a Diesel OSCE, however, such CR reduction has noticeable influence on ignition delay and combustion. Here it is most advisable to compensate smaller CR with intake air heating and boosting to achieve relevant evaporation, ignition and combustion conditions.

\section{A single cylinder test bed system}

Operating an OSCE is best accomplished with a modular test bed platform system comprising mod-
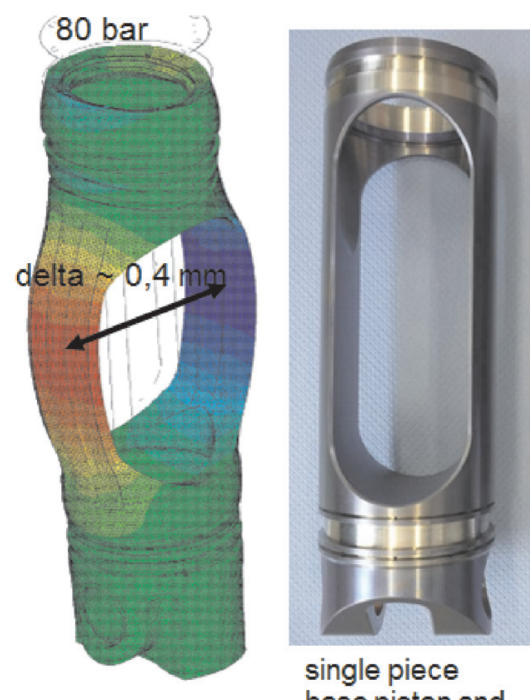

single piece base piston and piston rod
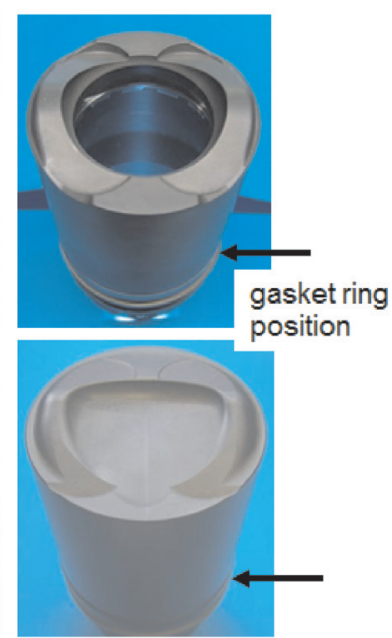

GDI piston crown examples

Fig. 3. Elongated piston for OSCE: load analysis for the piston rod (left) and piston components for a GDI application (right) - notice the low position of piston gasket ring

Rys. 3. Wydtużony tłok dla silnika typu OSCE: analiza obcią̇enia wydtużonego tłoka (z lewej) oraz elementy tłoka dla silnika typu GDI (z prawej) - zwraca uwage niskie umiejscowienie tłokowych pierścieni uszczelniających ules as shown in the schematic of Fig. 4. The core parts of such system are the engine and dyno, but productive test operation most often requires a number of peripheral components for:

- engine conditioning,

- media supply and conditioning,

- control of dyno, engine and measurement modules,

- fuel injection system,

- safety actuators and control software,

- measurement modules,

- user interfaces to access all signals and actuators.

Organizing the complexity of such installations is best accomplished in a modular platform architecture with well defined interfaces between required system modules.

\section{An OSCE measurement example}

The screenshots in Fig. 5 give a typical example for operating an OSCE, here with a GDI head configuration. Crank angle resolved operating signals are recorded continuously together with image sequences of in-cylinder events. The total group of fired cycles together with motored cycles before and after fuel injection is available for analysis. Cycle specific engine operation data, camera control signals and also emissions signals are accessible. As the OSCE must only be fired for a limited number of cycles, engine operation, synchronization with actuators and measurement devices and control of operating limits is performed within the measurement control system.

\section{OSCE data evaluation examples}

\subsection{GDI sprays and mixture formation}

Understanding fuel injection and mixture formation processes in GDI engines is of central importance for the

części tulei. To powoduje zauważalne zmniejszenie geometrycznego stopnia sprężania silnika.

\section{Uwagi odnośnie do stopnia sprężania}

Pierścienie tłokowe w silnikach OSCE są umieszczane niżej niż w tłokach konwencjonalnych. To niskie umieszczenie razem z typową wielkością luzu tłokowego $0,5 \mathrm{~mm}$ zwiększa objętość komory spalania i zmniejsza stopień sprężania o 1 do 3 jednostek.

W silniku o ZI takie zmniejszenie stopnia sprężania jest najczęściej akceptowalne, gdyż głównym celem stosowania silnika typu OSCE jest analiza tworzenia mieszanki podczas suwów dolotu i sprężania. Jednak w optycznym silniku o ZS takie zmniejszenie stopnia sprężania ma zauważalny wpływ na opóźnienie samozapłonu i spalanie. Najbardziej zalecane wtedy jest skompensowanie mniejszego stopnia sprężania przez podgrzewanie świeżego ładunku i doładowanie w celu osiągnięcia odpowiednich warunków dla odparowania paliwa, zapłonu i spalania.

\section{System badawczy z silnikiem jednocylindrowym}

Praca silnika typu OCE jest najlepiej realizowana na modułowym stanowisku badawczym obejmującym moduły konstrukcyjne (rys. 4). Głównymi elementami takiego systemu są silnik i hamulec, ale prowadzenie skutecznych badań zwykle wymaga wielu urządzeń dodatkowych dla:

- kondycjonowania silnika,

- dostarczania mediów i ich kondycjonowania,

- sterowania hamulcem, silnikiem i modułami pomiarowymi,

- systemu wtrysku paliwa, 


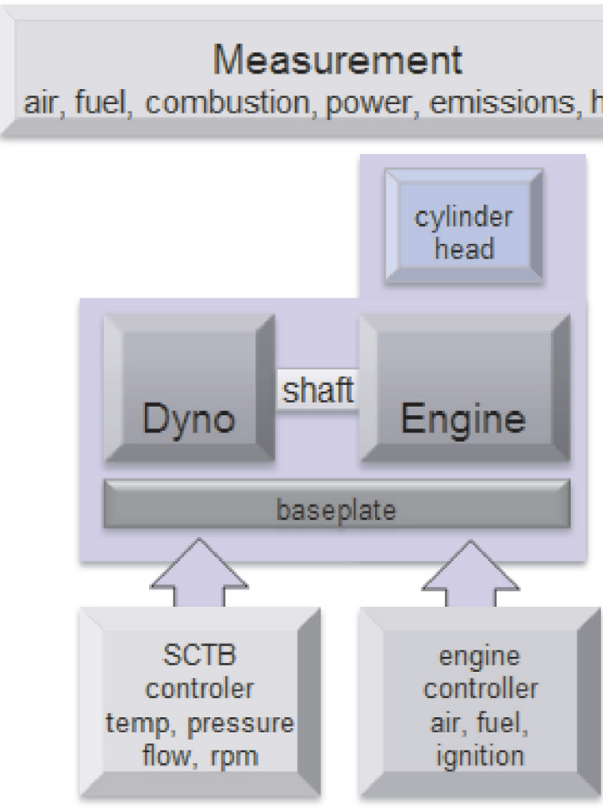

Supply and Conditioning air, fuel, oil, heating/cooling, exhaust

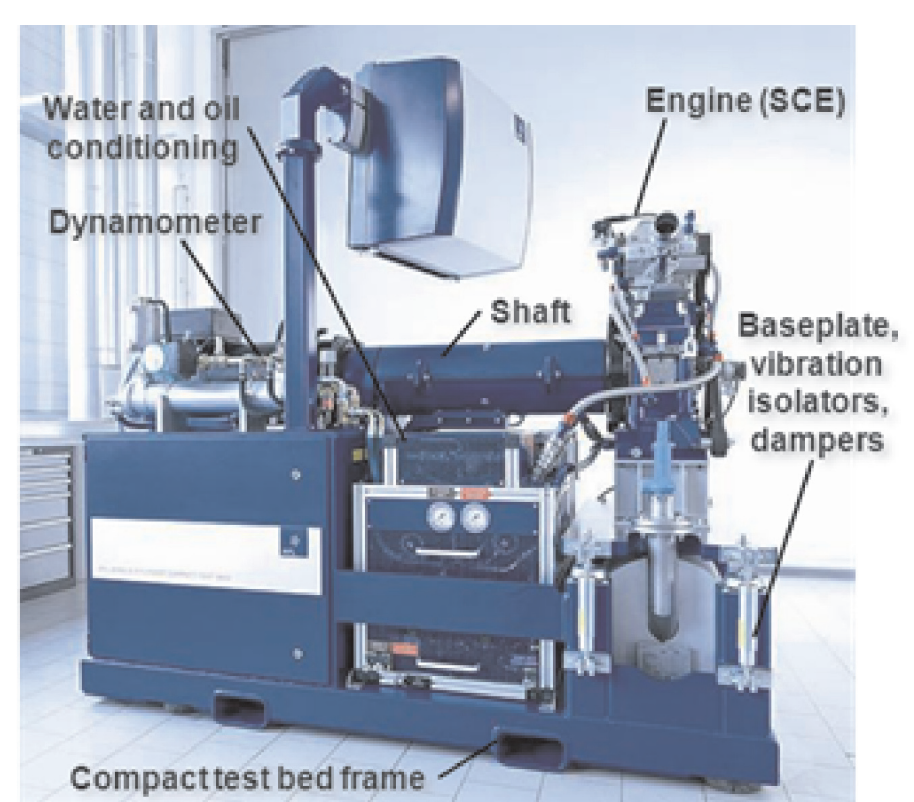

Fig. 4. Schematic of a test bed platform system, example of a "compact test bed" configuration dedicated to SCE operation.

Rys. 4. Schemat stanowiska badawczego, przykład stanowiska kompaktowego dedykowanego silnikowi jednocylindrowemu

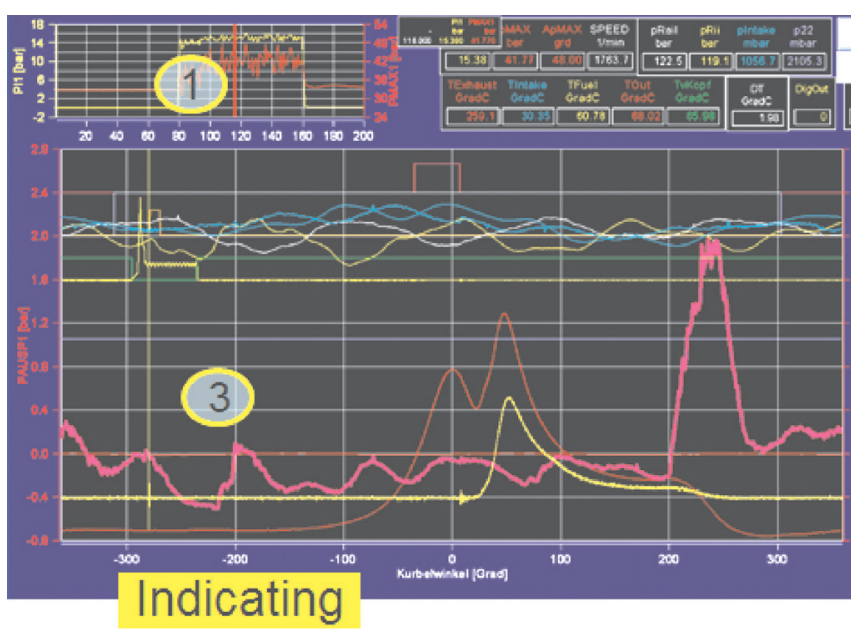

Fig. 5. OSCE operation for a group of fired cycles (1) with single shot snapshots recorded with a synchronized camera (2). Display shows crank angle resolved data (3) for the specific cycle with the spray snapshot (4). Exhaust gas emissions data are used to identify stationary combustion conditions and emissions trends

Rys. 5. Praca OSCE dla kolejnych cykli spalania (1) z pojedynczymi zrzutami ekranów pomiarowych zsynchronizowana kamera stroboskopowa (2). Zdjęcia pokazują dane pomiarowe zsynchronizowane z katem obrotu watu korbowego (3) dla określonego cyklu ze sfilmowana struga paliwa (4). Wyniki pomiarów emisji spalin wykorzystano do identyfikacji stacjonarnych warunków spalania i tendencji zmian emisji

development of reliable and clean combustion systems. Consequently, the analysis and optimization of such processes has become an important part of GDI system development. An OSCE provides the ideal environment to study GDI injection and mixture formation events.
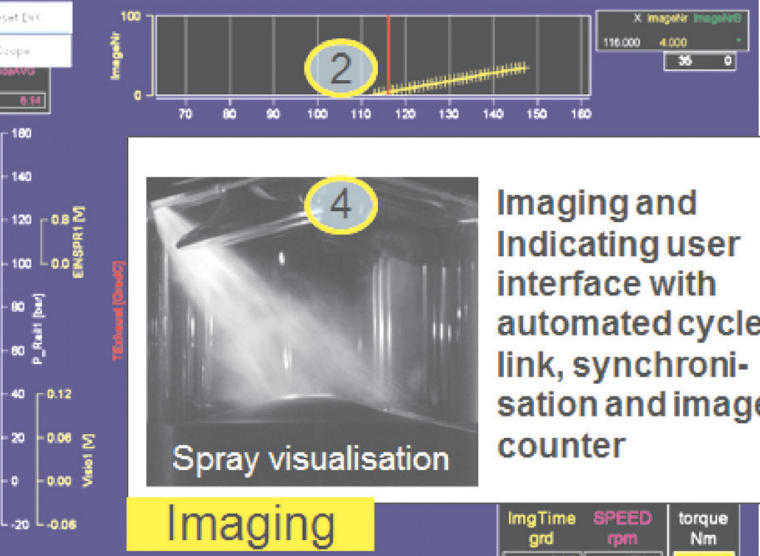

Imaging and Indicating user interface with automated cycle link, synchronisation and image counter

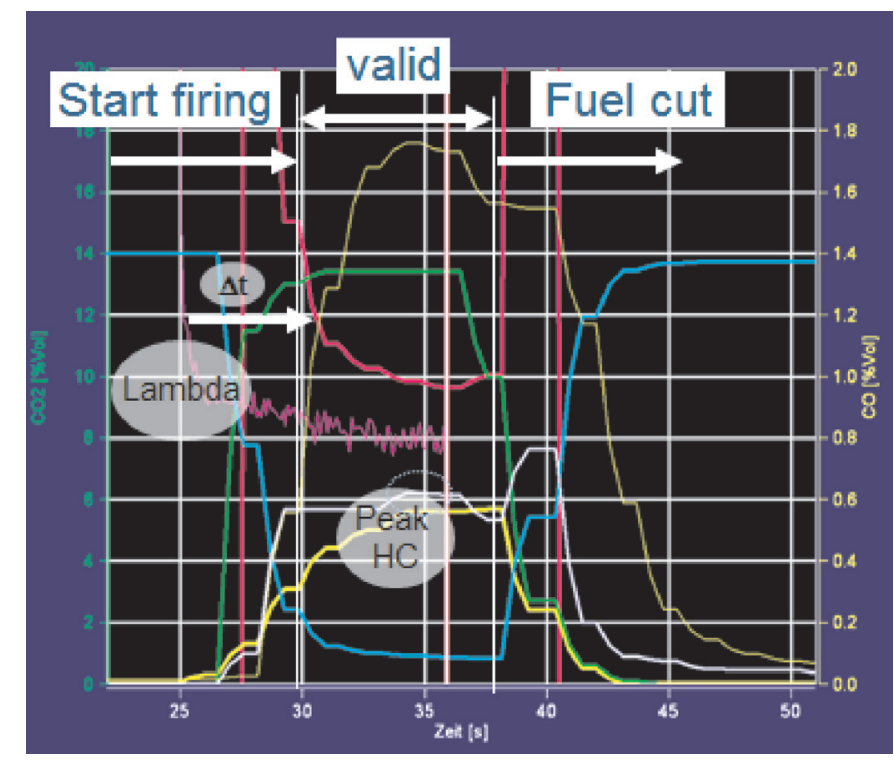


The example of laser induced fluorescence imaging (LIF) of fuel sprays in Fig. 6 shows a single shot LIF image together with a method for statistical image analysis. Application of such statistic image diagnostics gives a reliable guideline for the selection of best suited injectors and their operating parameters [2].

The method: Planar LIF image of GDI spray to derive
statistic spray distribution data from single cycle snapshots
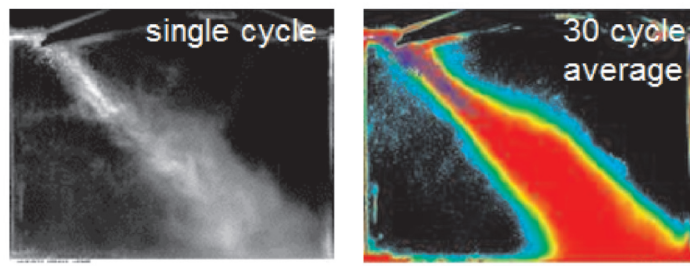

The benefit: find injector and injector operation parameters for best fuel homogenization
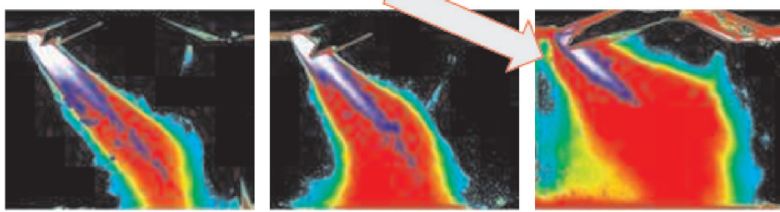

Fig. 6. LIF spray imaging in a GDI OSCE to support selection of injector variants

Rys. 6. Filmowanie strugi metoda LIF w jednocylindrowym silniku optycznym typu GDI dla wspomagania wyboru rodzaju wtryskiwacza

\subsection{Flame evaluation}

Even if compression ratios in an OSCE configuration are smaller than in a normal engine, and even if spark timing may be retarded to avoid knock or riskfull combustion pressure, flame evaluation in GDI configurations was found to provide most useful information about premixed and diffusion flame combustion. As diffusion flames are sources for particle emissions, developing injection and airflow configurations for soot free combustion is mandatory in meeting forthcoming Euro 6 particle emissions limits [3].

In an OSCE, flame features are recorded with high speed or single shot cameras, yielding flame image information as shown Fig. 7. Premixed and diffusion flames are easily distinguished because of their specific radiation properties. Again, for engineering purposes, it is mandatory to use statistic image information in order to support decisions on best operating variants.

\section{Summary}

OSCEs offer specific chances for highly detailed diagnostics of engine phenomena. This has always been the driving motive for their application in research projects. The refinement of modern engine systems and their growing complexity to achieve fuel efficiency and emissions targets requires application of OSCEs even in the development of production engines. As an OSCE can only partially duplicate MCE behavior, care must be taken in deciding on the most effective use of an OSCE to support engine development.
- siłowników bezpieczeństwa i oprogramowania sterującego,

- modułów pomiarowych,

- interfejsów użytkownika dla dostępu do wszystkich sygnałów i siłowników.

Organizacja i złożoność takich instalacji są najlepiej realizowane z zastosowaniem budowy modułowej z dobrze zdefiniowanymi interfejsami łączącymi wymagane moduły systemowe.

\section{Przykład pomiarów na optycznym silniku jednocylindrowym (OSCE)}

Zaprezentowane na rys. 5 zdjęcia ekranów komputerowych pokazują typowy przykład pracy silnika OSCE (tutaj z głowicą typu GDI). W sposób ciągły rejestrowane są sygnały operacyjne silnika w funkcji kąta obrotu wału korbowego razem z sekwencją zdjęć procesów wewnątrzcylindrowych. Do analizy uzyskuje się sekwencję kolejnych cykli spalania razem z cyklami pracy silnika przed rozpoczęciem i po zakończeniu wtrysku paliwa. Dostępne są dane operacyjne silnika właściwe dla poszczególnych cykli roboczych, sygnały sterujące kamery oraz sygnały pomiarowe emisji związków szkodliwych. Ponieważ silnik typu OSCE może pracować ze spalaniem tylko przez ograniczoną liczbę cykli roboczych, praca silnika, synchronizacja siłowników wykonawczych i elementów pomiarowych oraz kontrola ograniczeń operacyjnych jest prowadzona przez system sterowania pomiarami.

\section{Przykłady wyników z silnika OSCE}

\subsection{Struga paliwa i tworzenie mieszanki w silniku GDI}

Zrozumienie procesów wtrysku paliwa i tworzenia mieszanki w silnikach typu GDI ma podstawowe znaczenie dla rozwoju niezawodnych i niskoemisyjnych systemów spalania. W rezultacie analiza i optymalizacja takich procesów stały się ważną częścią rozwoju systemów GDI. Jednocylindrowy silnik optyczny (OSCE) zapewnia idealne środowisko dla studiów nad procesami wtrysku i tworzenia mieszanki w silnikach GDI.

Przykład filmowania strugi paliwa z wykorzystaniem metody LIF (Laser Induced Fluorescence) - rys. 6 - pokazuje pojedyncze zdjęcie strugi razem $\mathrm{z}$ analizą statystyczną fotografii kolejnych cykli. Zastosowanie takiej statystycznej analizy fotograficznej pozwala uzyskać niezawodne wytyczne do wyboru najlepszego wtryskiwacza i jego parametrów operacyjnych [2].

\subsection{Rozprzestrzenianie płomienia}

Nawet wówczas, gdy stopień sprężania w silniku optycznym OSCE jest mniejszy niż w silniku konwencjonalnym, i nawet jeżeli chwila zapłonu musi być opóźniona dla uniknięcia spalania stukowego lub niebezpiecznie dużego ciśnienia spalania, to stwierdzona propagacja płomienia w silnikach typu GDI została uznana jako zapewniająca najbardziej użyteczną informację dotyczącą spalania kinetycznego i dyfuzyjnego. Jeżeli uzna się, że płomienie dyfuzyjne są źródłem emisji cząstek stałych, to rozwijając systemy wtrysku paliwa i przepływu powietrza dla bezdymnego spalania, 


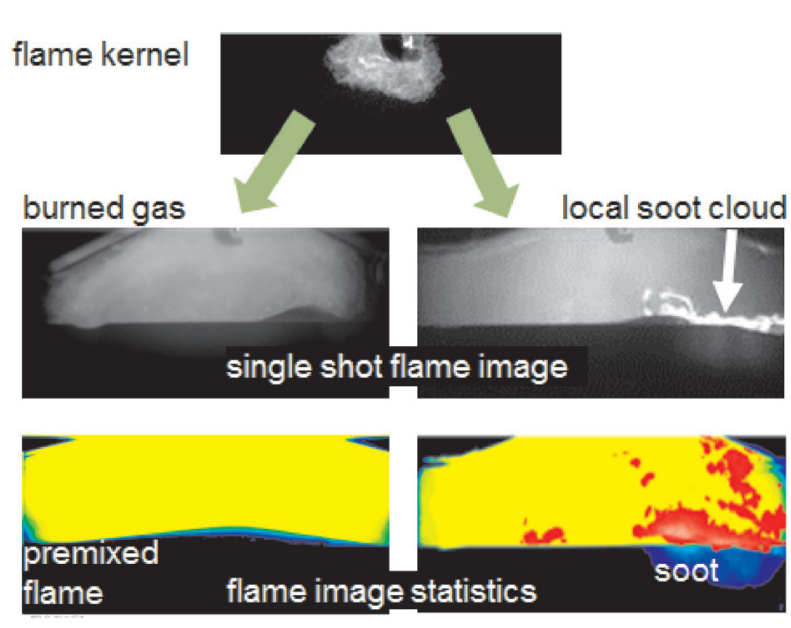

Fig. 7. Flame analysis shows premixed combustion situation (left hand) and appearance of soot clouds as a result of wall film combustion (right side). Imaging and data evaluation procedures provide statistic image evaluation

Rys. 7. Analiza płomienia pokazuje spalanie kinetyczne (lewa strona) $i$ powstawanie chmury sadzy jako rezultat spalania warstwy naściennej (prawa strona). Procedury filmowania i przetwarzania danych zapewniaja obróbkę statystyczną obrazów

This paper has given a comparison of MCE versus OSCE features and provided examples of OSCE applications in basic development phases of GDI engines.

OSCE measurement techniques may comprise of complex optical, thermodynamic or emissions diagnostic systems. In order to make efficient use of such systems, the complexity of these systems is handled within a combustion measurement platform providing for the modular adaptation and growth of the diagnostic techniques.

Operation of an OSCE together with peripheral equipment and engine safeguard modules is handled within a modular test bed platform. można zapewnić spełnienie przyszłych norm emisji cząstek stałych wg Euro 6 [3].

W silnikach optycznych (OSCE) właściwości płomienne są filmowane $\mathrm{z}$ wykorzystaniem kamer do szybkiego filmowania lub do filmowania stroboskopowego, co pozwala uzyskać obrazy płomienia takie, jakie pokazano na rys. 7 . Płomienie kinetyczne i dyfuzyjne są łatwo rozróżnialne ze względu na ich specyficzne właściwości radiacyjne. Także tutaj, dla celów silnikowych, jest konieczne zastosowanie statystycznej obróbki zdjęć w celu wspomagania decyzji wyboru najlepszych wariantów operacyjnych.

\section{Podsumowanie}

Jednocylindrowe silniki optyczne (OSCE) umożliwiają specyficzne modyfikacje dla szczegółowej diagnostyki zjawisk silnikowych. Jest to zwykle podstawą ich zastosowania w projektach badawczych. Ulepszenie systemów składowych nowoczesnych silników spalinowych i ich zwiększająca się złożoność dla osiągnięcia oszczędności paliwa i celów emisyjnych wymaga stosowania silników OSCE także w rozwoju silników seryjnych. Ponieważ silnik OSCE może tylko częściowo odtworzyć działanie silnika wielocylindrowego, należy zwrócić szczególną uwagę na jak najefektywniejsze wykorzystanie silników OSCE do wspomagania prac rozwojowych. To opracowanie wskazuje porównanie właściwości silnika wielocylindrowego MCE w stosunku do silnika OSCE i przedstawia przykłady zastosowania silnika OSCE do elementarnego rozwoju silników GDI.

Techniki pomiarowe w silniku OSCE mogą obejmować złożone systemy diagnostyczne: optyczne, termodynamiczne i emisyjne. W celu zapewnienia wydajnego zastosowania takich systemów, ich złożoność jest zapewniana na stanowisku pomiarów spalania zapewniającym przystosowanie modułowe i rozbudowę technik diagnostycznych.

Wykorzystanie silnika optycznego OSCE razem z wyposażeniem towarzyszącym i systemami bezpieczeństwa jest umożliwione w modułowym stanowisku badawczym.

\section{Bibliography/Literatura}

[1] Hopfner W., Loecker A., Winklhofer E.: Single cylinder engines - the test environment for combustion R\&D, Car Romania 2011.

[2] Fuchs H., Hopfner W., Kapus P., Winklhofer E.: Methods and criteria for fuel injector integration in boosted gasoline direct injection engines, IMECHE conference on "Injection systems for IC engines" 13 - 14 May 2009, London.

[3] Fraidl G., Winklhofer E.: Developing clean GDI systems to meet Euro 6 targets, 10th International Symposium on Combustion Diagnostics, 22/23 May Baden-Baden, Germany 2012.

Ernst Winklhofer, DEng. - skill team leader for optical technologies at AVL List GmbH, Austria.

Dr inż. Ernst Winklhofer-kierownik zespotu technologii optycznych AVL List GmbH, Austria. e-mail: ernst.winklhofer@avl.com

\section{Nomenclature/Skróty i oznaczenia}

GDI - Gasoline Direct Injection/silnik benzynowy o wtrysku bezpośrednim

OSCE - Optical Single Cylinder Engine/jednocylindrowy silnik optyczny

MCE - Multi-Cylinder Engine/silnik wielocylindrowy

TSCE - Thermodynamic Single Cylinder Engine/jednocylindrowy silnik termodynamiczny

Wolfgang Hopfner, Eng. - Group Product Manager Single Cylinder Research Engines and Peripheral Equipment at AVL List GmbH, Graz, Austria.

Inż. Wolfgang Hopfner - kierownik zespolu badawczych silników jednocylindrowych i urzadzeń peryferyjnych w AVL List GmbH, Graz, Austria.

e-mail:wolfgang.hopfner@avl.com

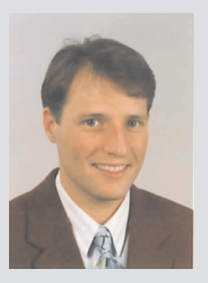

